\title{
MODIFICATION OF THE NEGATIVE PRESSURE THERAPY TECHNIQUE FOR TREATMENT OF WOUND INFECTION AFTER SPINAL SURGERY
}

\author{
MODIFICACÃO DA TÉCNICA DE TERAPIA DE PRESSÃO NEGATIVA PARA TRATAMENTO \\ DE INFECÇÃO DE FERIDA DEPOIS DE CIRURGIA DE COLUNA
}

\author{
MODIFICACIÓN DE LA TÉCNICA DE TERAPIA DE PRESIÓN NEGATIVA PARA TRATAMIENTO \\ DE INFECCIÓN DE LA HERIDA DESPUÉS DE CIRUGIÁ DE COLUMNA
}

Martin Betancourt-Carlos, ${ }^{1}$ Arelli Catalina González-Cisneros, ${ }^{2}$ José María Jiménez-AvilaA $^{1}$

1. Instituto Mexicano del Seguro Social, Centro Médico Nacional de Occidente, Orthopedics, Spine Clinic, Guadalajara, Jalisco, Mexico.

2. Instituto Tecnológico y de Estudios Superiores de Monterrey, Guadalajara, Jalisco, Mexico.

\begin{abstract}
Objective: To describe the indications and contraindications of negative pressure assisted wound therapy as well as a modification to the negative pressure technique that has been shown to shorten the number of changes of dressings and hospital stay with the early closure of the wound. Methods: A review of the existing literature in the databases OVID, PubMed, Cochrane and Medigraphic was carried out in relation to the pressure-assisted closure of wounds. This is a non-invasive and active healing system that uses localized and controlled negative pressure, which consists of a specialized dressing that includes reticulated foam that removes the exudates through a tube to an airtight container. This set forms microdeformations in the wound bed, which are known to cause an important increase in fibroblastic migration and consequently of higher quality tissue, granulation tissue formation and angiogenesis. Results: It was found that this method shortens the number of days of hospital stay. The technique describes the primary closure of the wound after intense cleansing and debridement of the non-viable tissue and signs of infection. Conclusions: Negative pressure wound therapy is effective for the treatment of deep infections in postsurgical spinal wound, with average time of use of 1 to 4 weeks in the most severe cases. Level of evidence IV; Case Series.
\end{abstract}

Keywords: Negative-Pressure Wound Therapy; Infection; Spine.

\section{RESUMO}

Objetivo: Descrever as indicações e contraindicações da terapia de cicatrização assistida pela pressão negativa, assim como uma modificação nessa técnica, que demonstrou diminuir o número de recargas de curativos e de internação hospitalar, por meio da manipulação do fechamento precoce de feridas. Métodos: Foi realizada uma revisão da literatura, em bases de dados da OVID, PubMed, Cochrane e Medigraphic, sobre a terapia de cicatrização assistida pela pressão negativa. Este é um sistema ativo de cura não invasivo utilizando pressão negativa controlada e localizada, que consiste em um curativo especializado, com a inclusão de uma espuma reticulada que conduz, através de um tubo de exsudado, a um recipiente hermético, formando micro deformações no leito da ferida. A técnica tem provado ser uma importante causa do aumento da migração fibroblástica e, consequentemente, de tecido de qualidade mais elevada, junto com a formação de tecido de granulação e angiogénese. Resultados: Em relação à técnica, descreve-se as etapas como forma de fechamento primário da ferida após limpeza intensa, desbridamento da área não viável e das características infecciosas. Além disso, o uso da técnica demonstrou diminuir o número de dias de internação hospitalar. Conclusão: Este método de pressão negativa é eficaz para o tratamento de infecções pós-cirúrgicas profundas da coluna vertebral, sendo usado, em média, de um a quatro semanas nos casos mais graves. Nível de evidência IV; Série de Casos.

Descritores: Tratamento de Ferimentos com Pressão Negativa; Infecção; Coluna Vertebral.

\section{RESUMEN}

Objetivo: Describir las indicaciones y contraindicaciones de la terapia de cicatrización de heridas asistida por presión negativa, así como una modificación a la técnica de presión negativa que ha demostrado acortar el número de recambio de apósitos y la estancia hospitalaria con el cierre temprano de la herida. Métodos: Se realizó una revisión de la literatura existente en las bases de datos OVID, PubMed, Cochrane y Medigraphic en relación a la terapia de cicatrización de heridas asistida por presión negativa. Es un sistema de cicatrización no invasivo y activo que utiliza presión negativa localizada y controlada, que consiste de un apósito especializado que incluye esponja reticulada que elimina los exudados a través de un tubo a un recipiente hermético. Este conjunto forma micro deformaciones en el lecho de la herida, que se sabe que causan aumento importante de la migración fibroblástica y, por consiguiente, tejido de mayor calidad, formación de tejido de granulación y angiogénesis. Resultados: Se constató que este método acorta el número de días de estancia hospitalaria. La técnica describe el cierre primario de la herida después de limpieza intensa y desbridamiento del tejido no viable y de los signos de infección. Conclusiones: La terapia de heridas por presión negativa es eficaz para el tratamiento de las infecciones profundas de heridas en el postoperatorio de la columna vertebral, con un tiempo promedio de uso de 1 a 4 semanas en los casos más severos. Nivel de evidencia IV, Serie de Casos.

Descriptores: Terapia de Presión Negativa para Heridas; Infección; Columna Vertebral.

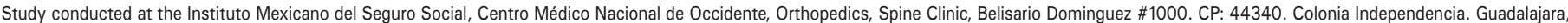
Jalisco, Mexico.

Correspondence: José María Jiménez Avila. Av. Normalistas, 442, Colinas de la Normal, Guadalajara, Jalisco, México. 44270. josemajimeneza@hotmail.com 


\section{INTRODUCTION}

Currently, even with knowledge of the biology of wounds and the new types of dressings available, a great number of wounds still fail to heal and become chronic. ${ }^{1-3}$

Negative pressure wound therapy (NPWT) is a way to act positively in a situation where a wound is stuck in the inflammation and proliferation stage and also with wounds that are in an acute state in order to reduce their complexity and avoid complications by applying subatmospheric pressure. The therapy has several names including subatmospheric dressing or therapy, vacuum sealing, vacuum-assisted closure, and vacuum packing, among others. ${ }^{1,4-7}$

Its mechanism of action is based on three levels of the wound healing process:

1. Removal of the excess interstitial fluid

2. Transmission of mechanical forces that stimulate tissue proliferation.

3. Maintenance of a suitable environment for the wound in terms of humidity and temperature. , $^{1,8-10}$

The first references to wound healing methods go back to Egyptian "healers" (asu), who probably did not know that, by applying a curative composed of animal fat, honey, and linen, they were using a dressing that was respectively non-adherent, osmotic and anti-bacterial, and capable of absorbing exudates.

Prior to 1960, wound management was focused on preventing infection, so after washing them with antiseptics, they were covered with a dry curative that would prevent bacterial development.

It was found that wounds that were kept moist healed more rapidly than those exposed to the air and since then the benefits of moist healing have been proven and are used daily in wound management.

As the biology of wounds has become better understood, the characteristics of ideal healing have also been defined. ${ }^{1,7,9,11-13}$

Negative pressure wound therapy (NPWT) is a non-invasive, active healing system that uses localized, controlled negative pressure. It consists of a specialized dressing that includes a reticulated foam with a specific porosity of 400 to 600 microns, which is sealed with a semi-occlusive antibacterial dressing, the objective of which is to maintain negative pressure at the wound site, carrying the exudate through a tube to an airtight container. Together these create microdeformities in the wound bed, which several studies have shown to be an important cause of greater fibroblast migration and, consequently, higher quality tissue, greater granulation tissue formation, and angiogenesis

The effectiveness of this process is due to:

1. Removal of fluids:

a. Decrease in pro-inflammatory factors or degraders of the extracellular matrix

b. Effective removal of microorganisms contained in the wound bed 2. Increase in capillary blood flow, four times greater

3. Increase in the formation of granulation tissue of up to $103 \%$

4. Promotion of a moist healing environment

5. Reduction in local swelling

There is currently no dressing that includes all these characteristics and several techniques and materials have been tested in search of the ideal dressing, such as alginates, hydrogels, collagen, and skin replacement products, which have proven useful for several types of wounds.

There are several devices in the experimentation and application phases, as yet not widespread, such as growth factors, pharmacological agents, laser, hyperbaric oxygen therapy, and electrical stimulation, and most of these are considered advanced wound care technologies. . $^{1,10,12,14}$

These are defined as those that affect the wound-healing process in an active and positive way by counteracting, eliminating, or significantly reducing at least two of the factors that can compromise this process.

Negative pressure wound therapy (NPWT) used alone or in association with other similar techniques increases the rates of wound healing. 3,7,10,15

Given the increases in life expectancy and in the number of people with chronic wounds, advanced healing techniques, among them NPWT, have become the primary, and often the only, therapeutic modality for those patients who require additional localized healing to achieve a surgical indication and opportunity or in those where surgical procedures have failed. $3,6,7,9$

These types of wounds are more likely to occur in the elderly or in people with multiple health problems because people are living much longer with more complex conditions and being submitted to more extensive surgical procedures. The number of people with chronic wounds and wound complications continues to grow and, despite medical and nursing care, some of these wounds do not heal easily and cause much discomfort and pain. ${ }^{1,4,16}$

The initial management of wounds is aimed at preventing infection, for example, washing the wound with antiseptic and covering it with a dry bandage that does not contain bacteria. In the 1950s and 1960s, research on wound healing revealed that acute wounds heal more rapidly if they are kept moist, since this allows the cells of the dermis and epidermis to divide and migrate to the wound surface. , $^{2,4,5,12}$

Despite the use of modern bandages, a large number of chronic wounds are still difficult to heal. One way to manipulate the wound environment is to apply negative topical pressure (NPWT) (measured in $\mathrm{mmHg}$ ) to the surface of the wound by means of a bandage. The concept of negative pressure to create an aspiration force that enables drainage of surgical wounds to stimulate would healing is well documented. ${ }^{1,2,5,8,9,14,17}$

It was long ago suggested that, if the excess liquid is not adequately eliminated from the wound following surgery, its components can act as physical and chemical impediments to the healing of the wound.

The basic concept that mechanical forces influence the shape and growth of tissue is also well documented. It has been reported that NPWT has both properties, that is, it removes excess interstitial liquid and transmits mechanical forces to the surrounding tissues with the resultant deformation of the extracellular matrix and the cells. ${ }^{8-10,18,19}$

It is assumed that both factors stimulate the healing of the wound through a variety of mechanisms. The transparent adhesive bandage used to secure the dressing also can help to maintain a humid wound environment.

There are several terms to describe the treatment of a wound with NPWT, including subatmospheric dressing or therapy, the vacuum sealing technique, vacuum assisted wound closure, suction foam bandage, vacuum compression, vacuum compress or aspiration of the wound with a sealed surface. For the purposes of this review, the intervention will be referred to as NPWT.8,10,12,13,20

NPWT requires a bandage with open cells (for example, foam, felt, surgical toweling, gauze) to compress the wound, a tubular structure to connect the bandage to a suction pump with an intermediate receptacle that collects any exudate that might exist, and a hermetic seal around the bandage. However, there is sufficient evidence that shows that dressings with a specific porosity of from 400 to 600 microns are the only ones capable of achieving microdeformation in the tissue.

All non-viable tissue is removed in advance. NPWT is generally contraindicated if the wound and surrounding tissue are cancerous, if there are fistulas that communicate with organs or cavities, in cases where a cerebrospinal fluid fistula is suspected, or if there is necrotic tissue or untreated osteomyelitis. ${ }^{1,3,7}$

Laboratory evidence about the effect of NPWT on the wound environment has been obtained through several animal studies. One series of studies using a model of a pig with acute wounds reported an increase in local functional blood perfusion, a significantly faster rate of granulation tissue formation, a significant decrease in tissue bacteria levels, and a significant increase in blood flow in wounds treated with NPWT, as compared to wounds treated with gauze moistened with physiological solution. 9,2,12,20,21

The use of NPWT in chronic human wounds has been described by a number of clinicians and its use for home treatment of chronic wounds has been reviewed using trials with simultaneous control groups.

This review examines the impact of NPWT on chronic human wounds using trials in which the patients have been randomly assigned to coexisting control groups. . $^{42,13,16,19}$

Likewise, we describe a new cutaneous closure and NPWT placement technique that enables a better, faster resolution to the infectious process.

As regards infection, the main focus of the treatment is drainage of all purulent material, removal of waste, devitalized tissue, and foreign bodies, and elimination of the etiology of the infection. ${ }^{4,5}$ 
For management of a complicated wound and the factors mentioned above, various therapies are used, such as surgical cleaning, higher-potency drugs, hyperbaric oxygen, among others, with acceptable results. However, in many cases it requires a long period of in-hospital medical care, with the consequent consumption of material and human resources: antibiotics, antiseptics, healing material, operating room hours, and physician or paramedical personnel, among others. ${ }^{9,22,23}$

The first function is performed by the computerized unit that extracts fluids from the wound, evacuated to a receptacle via a collector tube placed over the foam. This action speeds up the healing process by activating the cell division signal and by increasing blood flow. There are two types of sponges. The first is made of open-pore, hydrophobic polyurethane (400 to $600 \mu \mathrm{m}$ ), always indicated for the formation of granulation tissue when there are no exposed tendons, blood vessels, or nerves. In such cases, a hydrophilic polyvinyl alcohol foam will need to be used. Both have the property of transmitting the suction force to the bloody surface, where it causes microdeformations. An additional foam with the same characteristics as the polyurethane foam, but with the addition of silver, is used for infected wounds. $8,10,11,15$

The foam is designed with open pores to facilitate the elimination of excess exudate from the wound. It transmits subatmospheric pressure to the wound, an action that causes modifications in the wound surface in contact with it, inducing acceleration of the healing process. The adhesive film maintains a humid environment, with the characteristic of being permeable, which facilitates gaseous exchange and together with the foam, protects the wound from environmental contaminants. ${ }^{1,12,24,25}$

It has also been shown that negative pressure increases blood flow by reducing the swelling around the wound and by removing harmful enzymes from the wound bed. ${ }^{1,12}$

The indications for NPWT are acute, chronic, and traumatic wounds, burns, ulcers from diabetes, bed sores, and open abdominal surgery wounds. It is contraindicated for wounds with necrotic tissues, untreated osteomyelitis, and non-enteric unexplored fistulas and it is not recommended for use is areas of malignant neoplasm.

A modification was made to the NPWT technique in those patients with postoperative dehiscence of the surgical wound following spinal instrumentation.

The main modification consists of almost complete primary closure of the wound. The technique is described step by step, as follows.

a. Deep cleanse the wound dehiscence with 3-5 liters of $9 \%$ saline solution, continuing with debridement of all non-viable tissue and any tissue with characteristics of infection.

b. Remove approximately $2-3 \mathrm{~mm}$ of the cutaneous margins of the dehiscent wound, including subcutaneous cell tissue and skin.

c. Continue with closure by case planes for $70 \%$ of the length of the wound with vicryl 1-0 for the deep planes and nylon 2-0 with tension-free stitches for the skin.

d. Continue with placement of "strips" of silver foam around the opening of the wound, up to the deep planes (making sure to cover any bone tissue with polyvinyl alcohol dressing to avoid injury to them). Then perform the partial closure of the rest of the wound. (Figure 1)

e. It is important to note that the bandages must be changed at least every 5 days, since waiting any longer will make it difficult to completely remove the foam "strips" introduced into the wound.

f. Twelve (12) days after using NPWT the sutures can be removed from the first part of the closure. (Figure 2)

g. Twenty-four (24) days after the initial placement of the negative pressure system and with any exudate totaling less than 100cc in 72 hours, perform final closure of the wound (resulting wound is less than $3 \mathrm{~cm}$ ), monitoring it until removal of the sutures. (Figure 3)

Note: In patients with less than $100 \mathrm{cc}$ of exudate at the time of the first dressing change, the negative pressure system can be removed and final closure of the wound performed, with minimal risk of wound reopening.

By performing initial wound closure, following cleansing, selective debridement, and the placement of strips of foam dressing impregnated with silver between the muscle fascia and the subcutaneous cell tissue, reduced pressure on the skin is achieved, favoring

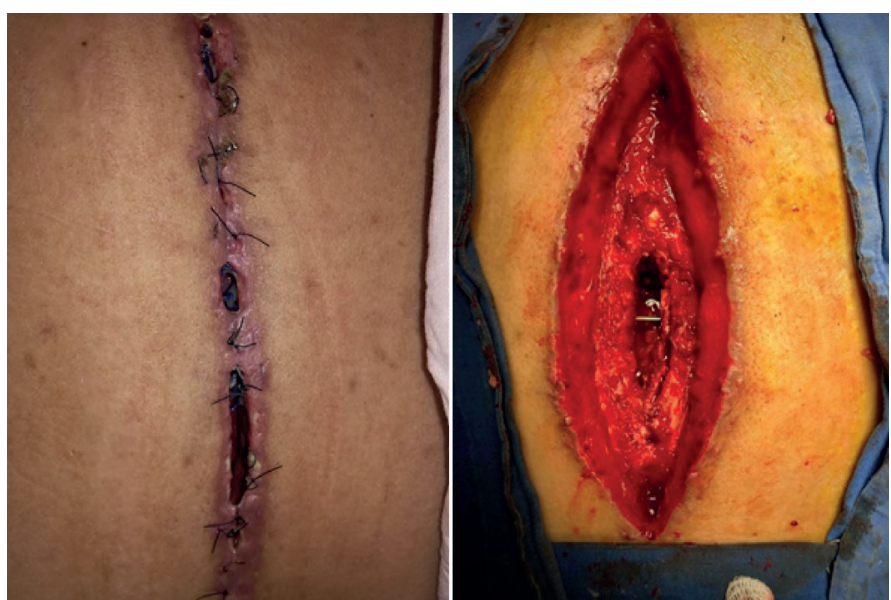

Figure 1. Male patient with dehiscence of the surgical wound after instrumentation for a fracture of $L 2$.

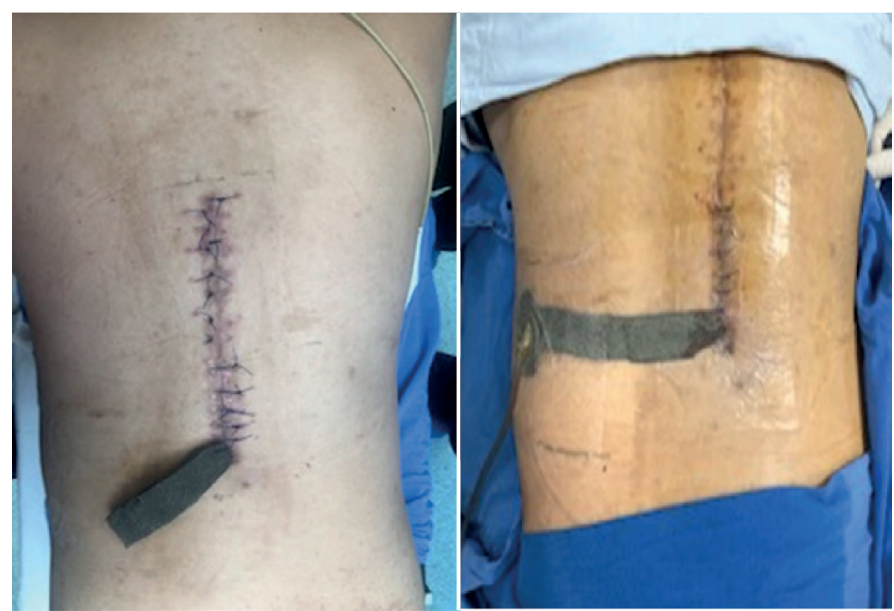

Figure 2. Initially, debridement and almost complete cutaneous closure are performed with the application of negative pressure, with bridging to the T.R.A.C. ${ }^{\circledR}$ site.

early closure of the wound, as well as continuous cleaning of the wound through negative pressure and achieving early resolution of infection and closure in a short period of time.

By removing excess fluid from the bloody area, compression is reduced, favoring the lymphatic and circulatory systems. Greater pressure hinders oxygenation and the passage of nutrients. Isolating the wound eliminates or reduces the bacterial load, which consumes nutrients, oxygen, and denatured proteins, with damage to the healing process. (Figure 4)

This type of therapy has been accepted in spine surgery. Its usefulness is of great help if one considers the high cost of the instrumentation used in this type of surgery. One of the contraindications is suspicion of the presence of rupture or tear of the dura mater with possible leakage of the cerebrospinal fluid. ${ }^{1,3,6,7,23}$

\section{METHODS}

A review of the existing literature in the databases OVID, PubMed, Cochrane and Medigraphic was carried out in relation to the pressure-assisted closure of wounds.

The study was approved by the Institutional Review Board as approval protocol number 216-1301-183.

\section{CONCLUSION}

Deep infections following spine surgery are a very significant cause of morbidity and mortality, with an incidence of from $0.9 \%$ to $13.4 \%$ of all surgical procedures. This is a very serious problem for 


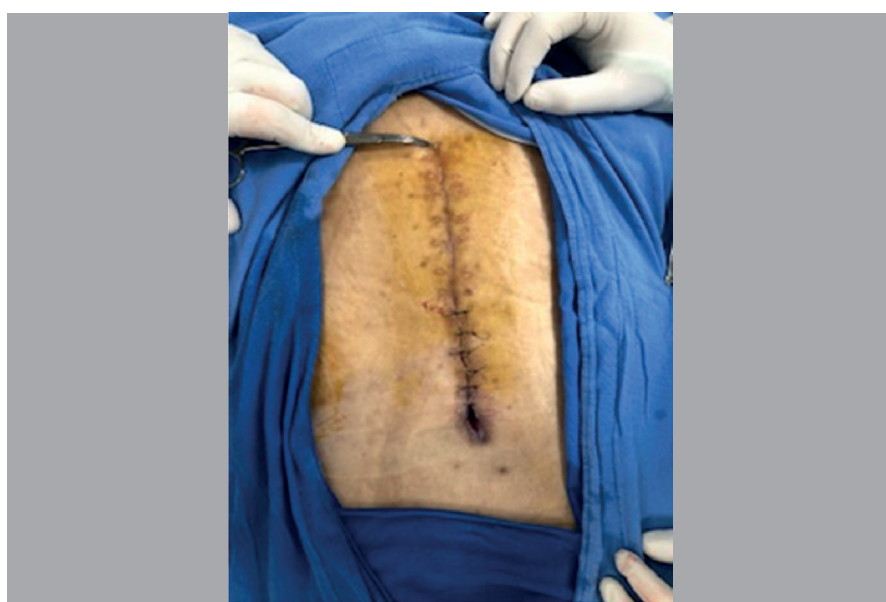

Figure 3. 14 days following closure of the wound, the sutures are removed and the final segment is closed.

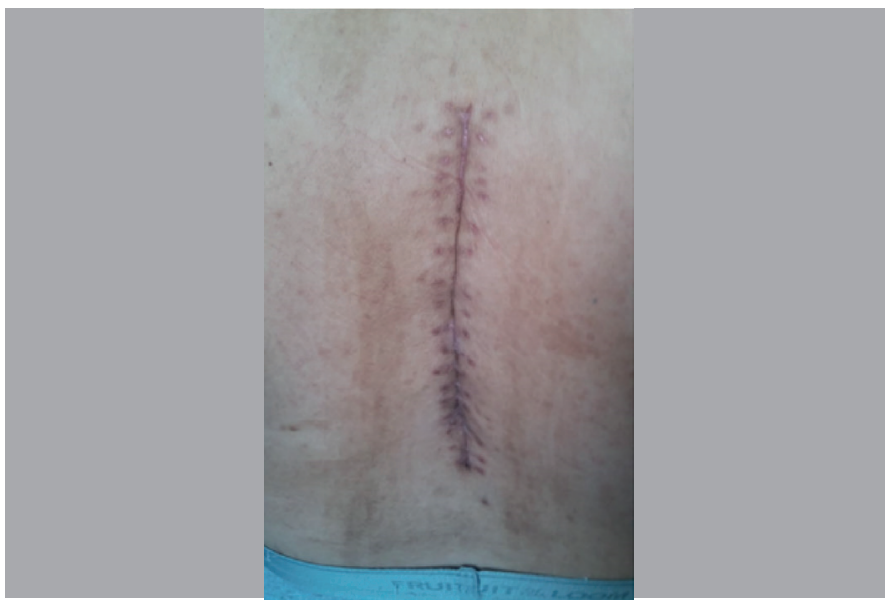

Figure 4. Removal of stitches 5 weeks following initial intervention with NPWT. Complete wound closure. the patient and for every level of the healthcare team.

Negative pressure wound therapy is used with great success, mainly in abdominal surgery, chest surgery involving sternal opening, and in exposed fractures of the lower limbs, as through negative pressure it eliminates and absorbs edema and fluids, improving blood circulation and generating cell proliferation with granulated tissue, as well as local tissue growth factors.

In addition, it has been shown that the use of negative pressure therapy reduces patient care costs, since the economic savings derived from more rapid healing, the shorter time spent by medical and paramedical personnel, the shorter hospitalization, and the decreased duration of antibiotic use compensate the costs of acquiring the dressing for negative pressure treatment.

The technique that we have developed has proven to be effective in the management of dehiscent wounds of the spine and of other orthopedic surgery sites.

This method is effective for the treatment of deep postoperative infections of the spine when used for an average of 1 to 4 weeks, the duration being influenced by whether there is exposure of inert material, by changing the foam and adhesive film three times a week, and performing repeated debridement and exhaustive cleansings until complete closure of the wound is achieved. It has a significant success rate without removal of the exposed implant.

The modification of NPWT was made mainly due to the growing rate of patients with infection of the surgical wound following spinal intervention.

Add to this the negative pressure technique, which offers shorter hospital stays, reduces antimicrobial therapy time, lowers medical care costs, and returns the patient to daily activities in the shortest possible time.

Infection associated with healthcare, known as nosocomial, is the localized or systemic infection resulting from an adverse reaction to the presence of an infectious agent.

In the United States, this type of infection causes more than 100,000 deaths each year with an annual cost of around $\$ 6.7$ billion.

In Mexico, the incidence of infection at the surgical site following a decompressive laminectomy, discectomy, and fusion is less than $3 \%$, but the incidence rises to $12 \%$ when the patient is instrumented.

All authors declare no potential conflict of interest related to this article.

CONTRIBUTION OF THE AUTHORS: Each author made significant individual contributions to this manuscript. JMJA (0000-0002-5532-5318)* and

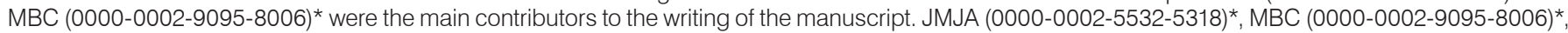
and ACGC (0000-0002-4278-5024)* performed the surgeries, followed-up with the patients, and collected the clinical data. MCB, JMJA, and ACGC conducted the bibliographical research, reviewed the manuscript, and contributed to the intellectual concept of the study. ${ }^{*}$ ORCID (Open Researcher and Contributor ID)

\section{REFERENCES}

1. Antony S, Terrazas S. A retrospective study: clinical experience using vacuum-assisted closure in the treatment of wounds. J Natl Med Assoc. 2004;96(8):1073-7.

2. Labler L, Keel M, Trentz O, Heinzelmann M. Wound conditioning by vacuum assisted closure (V.A.C.) in postoperative infections after dorsal spine surgery. Eur Spine J. 2006:15(9):1388-96

3. Morykwas MJ, Faler BJ, Pearce DJ, Argenta LC. Effects of varying levels of subatmospheric pressure on the rate of granulation tissue formation in experimental wounds in swine. Ann Plast Surg. 2001:47(5):547-51.

4. Brox-Jiménez A, Díaz-Gómez D, Parra-Membrives P, Martínez-Baena D, Márquez-Muñoz M, Lorente-Herce J, et al. [A vacuum assisted closure system in complex wounds: a retrospective study]. Cir Esp. 2010:87(5):312-7.

5. Dunn RM, Ignotz R, Mole T, Cockwill J, Smith JM. Assessment of gauze-based negative pressure wound therapy in the split-thickness skin graft clinical pathway-an observational study. Eplasty. 2011:11:e14

6. Nain PS, Uppal SK, Garg R, Bajaj K, Garg S. Role of negative pressure wound therapy in healing of diabetic foot ulcers. J Surg Tech Case Rep. 2011;3(1):17-22.

7. Yuste BV, Rodrigo PJ Silva BM, Monclús FE Gómez-Escolar L Tratamiento mediante presion negativa VAC de herida infectada tras artrodesis raquídea. Cir Plast Iberolatinoam. 2011:37(1):S73-6

8. Kolios L, Kolios G, Beyersdorff M, Dumont C, Stromps J, Freytag S, et al. Cost analysis of Topical Negative Pressure (TNP) Therapy for traumatic acquired wounds. Ger Med Sci. 2010;8:Doc13

9. Malmsjö M, Gustafsson L, Lindstedt S, Gesslein B, Ingemansson R. The effects of variable intermittent, and continuous negative pressure wound therapy, using foam or gauze on wound contraction, granulation tissue formation, and ingrowth into the wound filler. Eplasty. 2012;12:e5 
10. Ortega-León LH, Vargas-Domínguez A, Ramírez-Tapia D, Zaldívar-Ramírez FR, Rodríguez -Báez A, Montalvo-Javé E. Empleo de la presión negativa en el tratamiento de heridas complicadas. Reporte de seis casos. Cir Gen. 2011;33(2):115-20.

11. Hsu CC, Tsai WC, Chen CP, Lu YM, Wang JS. Effects of negative pressures on epithelial tight junctions and migration in wound healing. Am J Physiol Cell Physiol. 2010;299(2):C528-34

12. Singh K, Anderson E, Harper JG. Overview and management of sternal wound infection. Semin Plast Surg. 2011;25(1):25-33

13. Penn-Barwell JG, Fries CA, Street L, Jeffery $S$. Use of topical negative pressure in british servicemen with combat wounds. Eplasty. 2011;11:e35.

14. Armstrong DG, Jude EB. The role of matrix metalloproteinases in wound healing. J Am Podiatr Med Assoc. 2002;92(1):12-8.

15. Canavese F, Gupta S, Krajbich Jl, Emara KM. Vacuum-assisted closure for deep infection after spinal instrumentation for scoliosis. J Bone Joint Surg Br. 2008;90(3):377-81.

16. Saxena V, Hwang CW, Huang S, Eichbaum Q, Ingber D, Orgill DP. Vacuum-assisted closure: microdeformations of wounds and cell proliferation. Plast Reconstr Surg. 2004;114(5):1086-96.

17. Ortiz PN, Remondino R, González G, Catá CE. Infeccion profunda post quirurgica luego de una fusion espinal. Manejo con el sistema de cicatrizacion asistida por vacio. Rev Asoc Argent Ortop Traumatol. 2010;74(4):365-8.
18. Peinemann F, Sauerland S. Negative-pressure wound therapy: systematic review of randomized controlled trials. Dtsch Arztebl Int. 2011;108(22):381-9

19. Macedo FB, Carriquiry CE. Tratamiento de heridas utilizando presion negativa tópica. Biomedicina. 2006;2(2):122-30.

20. Gwan-Nulla DN, Casal RS. Toxic shock syndrome associated with the use of the vacuumassisted closure device. Ann Plast Surg. 2001:47(5):552-4.

21. Moffatt CJ, Soldevilla JJ. La presion negativa topica en el tratamiento de heridas. Documento de Posicionamiento. Wounds. 2007:19(1 Suppl):1-9.

22. Venturi ML, Attinger CE, Mesbahi AN, Hess CL, Graw KS. Mechanisms and clinical applications of the vacuum-assisted closure (VAC) Device: a review. Am J Clin Dermatol. 2005:6(3):185-94.

23. Jimenez-Avila JM, Calderon-Granados A, Bitar-Alatorre W. Costo directo de las lesiones en columna. Cir Cir. 2012;80:435-41.

24. Shi B, Chen SZ, Zhang P, Li JO. [Effects of vacuum-assisted closure (VAC) on the expressions of MMP-1, 2, 13 in human granulation wound]. Zhonghua Zheng Xing Wai Ke Za Zhi. 2003;19(4):279-81.

25. Horn PL, Ruth B, Kean JR. Use of wound V.A.C. therapy in pediatric patients with infected spinal wounds: a retrospective review. Orthop Nurs. 2007;26(5):317-22. 